\title{
ASI's Consensus Guidelines: ABCs of What to Do and What Not During the COVID-19 Pandemic
}

\author{
S. P. Somashekhar ${ }^{1} \cdot$ H. V. Shivaram ${ }^{2} \cdot$ Santhosh John Abhaham ${ }^{3} \cdot$ Abhay Dalvi $^{4} \cdot$ Arvind Kumar $^{5} \cdot$ Dilip Gode $^{6}$. \\ Shiva Misra ${ }^{7}$. Sanjay Kumar Jain ${ }^{8} \cdot$ C. R. K. Prasad $^{9} \cdot$ Raghu Ram Pillarisetti $^{10}$
}

Published online: 9 June 2020

(C) Association of Surgeons of India 2020

\section{Introduction}

The rapid pandemic status of coronavirus disease 2019 (COVID-19) caused by a novel virus - severe acute respiratory syndrome coronavirus 2 (SARS COV 2) - has taken tragic proportions and created havoc in health care systems across the globe. There has been a recent surge of COVID-19 infection in India. As of 26 May 2020, 145,380 new cases and 4167 deaths were reported in the country [1]. This potentially longwinding epidemic situation in India has overwhelmed the capacity of outpatient facilities, emergency departments (EDs), hospitals, and intensive care units, leading to critical shortages of staff, space, and supplies, resulting in patient outcomes and safety being compromised. This crisis resulted in significant challenges for decision-makers to balance the need for the

Raghu Ram Pillarisetti

p.raghuram@hotmail.com

S. P. Somashekhar

somusp@yahoo.com

1 Department of Surgical Oncology, Manipal Hospitals, Bengaluru, Karnataka, India

2 Department of Surgery and allied Specialties, Aster CM hospital, Bengaluru, Karnataka, India

3 Department of Surgery, Lourdes Hospital, Kochi, Kerala, India

4 The Association of Surgeons of India, Seth GS Medical College and KEM Hospital, Mumbai, Maharashtra, India

5 Centre for Chest Surgery, Sir Ganga Ram Hospital, New Delhi, India

6 Datta Meghe Institute Medical Sciences, Nagpur, Maharashtra, India

7 Shivani Hospital \& IVF, Utter Pradesh, Kanpur, India

8 Gandhi Medical college, Bhopal, Madhya Pradesh, India

9 PIMS, Hyderabad, Telangana, India

10 President ASI \& KIMS-USHALAKSHMI Centre for Breast Diseases, Hyderabad, Telangana, India continued delivery of other health services. Thus, it is essential to strengthen the health systems and reorganize the service delivery in response to COVID-19 crisis. During this rapidly changing environment, a set of evidence-based and consensus-driven guidelines from a professional expert peer group is the need of the hour.

Healthcare workers must determine a novel way to address issues such as - who should have surgery and how it should be performed. Strict personal and institutional practices need to be adopted, and policies to allow "new best practices" must be implemented to ensure the best prevention measures against COVID-19 infection in public, and indeed, private healthcare facilities. WHO has issued a wide range of technical guidance on the COVID-19 response emphasizing the important health system measures and policies reflecting clinical and public health action [2]. In addition, detailed guidelines were published by national and international bodies such as MOHFW [3] as well as SAGES and EAES [4] on surgical strategies in relation to COVID-19 crisis.

Although these guidelines are empirical, The Association of Surgeons of India (ASI) has embarked upon bringing out Consensus Statements that aim to empower the surgical fraternity in India with regard to decision making, resource allocation, infection prevention/control measures among patients and healthcare staff, indications for triage and management of cancer patients, prioritization of surgical approaches and maintaining core essential services across the continuum of care (Fig. 1). Based on frontline practical experiences and standard national as well as international guidelines as a framework to describe the recommendations, a panel of experts developed evidence-based Consensus Opinion on wide ranging issues, which is applicable to all public and private healthcare settings across India.

In the wake of the COVID-19 pandemic, these guidelines could help healthcare professionals provide timely, highquality surgical care that achieves the best outcomes for patients, while minimizing the risk of infection. 
Fig. 1 Depicting the various roles of a surgeon during COVID-19 pandemic

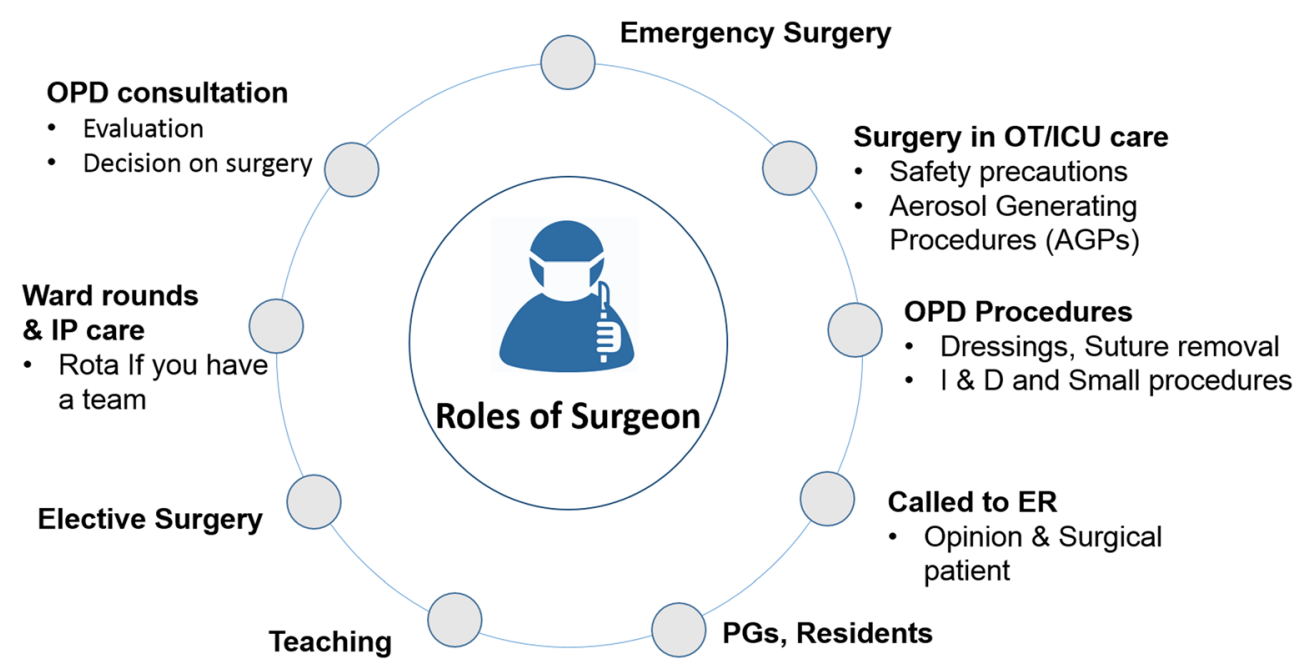

\section{Consensus Guidelines for Scheduling the Appointments}

Sticking to the guidelines for "social distancing" will ensure safety. Patient scheduling is a critical task to mitigate the spread of the novel coronavirus and to protect the patients, their families, and workforce by avoiding unnecessary exposure. Every patient visiting hospital should be wearing a mask and must be encouraged to fill up a comprehensive online registration form or seek prior appointment regarding purpose of hospital visit and urgency, which should also include with brief history about cough/fever. Only one entry/exit point should be permitted to the hospital, and strict hygiene measures such as hand sanitization at the entrance must be made mandatory to the patients. To rule out a fever, a temperature check must be performed.

Patients should be encouraged to visit the OPD alone (unless physically challenged), and it would be wise for patients to request their accompanying persons to stay in the car during his/her appointment. Minors must be allowed to be accompanied with only one parent/guardian to avoid crowding. Most importantly, it is crucial to ensure that patients inform the hospital right away regarding their travel history including of their household members and any signs of COVID-19 symptoms to reschedule the appointments in order to reduce the risk of contamination [6].

\section{Consensus Guidelines for the Management of Cancer Patients}

Cancer patients are more susceptible to COVID-19 infection because malignancy and anticancer therapy result in an immunosuppressive state [7]. There is evidence to suggest that cancer patients who contracted COVID-19 have more than triple the risk for severe health events including admission to the intensive care unit for invasive ventilation and rapid clinical by ASI for surgeons to pursue. 
Table 1 ASI general recommendations for surgeons
Dress code for surgeons

While leaving from home

- Wear simple dress with shoes and socks

- No accessories like watch, ring, tie, coat, wallet

- Wear mask

After reaching work place

- Change to hospital scrub suite

- Change the footwear on entering hospital premise

while donning scrubs

Commute to work place

- Best is to use own vehicle

- Avoid public transport as much as possible and Taxi approved by government (latest)
- Place the travel dress in a cupboard

- Wear appropriate mask

- Clean your mobile frequently before, during, and after patient care activities. Mobile phones may be kept in a Ziploc bag during work activities. The phone can be used while in the bag

While leaving hospital

- Remove the hospital scrub and subject it to proper wash

- Sanitize hands after getting in and after getting down the vehicle

- In case if commuted through public or shared vehicle, maintain physical distance.

Point of entry screening and check-in to protect both patients and healthcare

- Ensure separate entry for healthcare workers and for patients

- Staff members must ensure if patients are sanitizing hands and wearing mask properly or not.

- For patients - at the entry, a senior health care worker/staff nurse should check the temperature along with check-history of fever, signs of cough, throat pain, contact with fever patients and whether staying in red zone etc.

Measures to follow after reaching home

- Leave footwear outside

- Sanitize hand, car keys, mobile

- Remove the mask and dispose of appropriately

- Take shower and wear clean dress meant for home

- Clean hard surfaces at home with an effective disinfectant solution (e.g., $60 \%$ alcohol)

- If reusable cloth mask - put it for wash and rinsing with soap water

deterioration [8]. The case fatality rate was $5.6 \%$, higher than the overall reported case fatality (2.3\%) from COVID-19 [9]. Cancer is a semi-emergency disease and its treatment is timebound. There are 2 aspects to consider:

\section{- Impact of COVID per se on cancer patients \\ - Impact of cancer on COVID patients}

Several experts in an international position paper have published some suggestions on the management of cancer patients in the COVID-19 era [10]. Surgical Society of Oncology (SSO) in affiliation with BSO and ISO has proposed three categories for cancer management as depicted in Table 2. There is rapid deterioration of general condition in COVID-affected cancer patients. First golden rule as a doctor is, "Do no harm." Delay in treatment not only results in stage migration and a need for more radiotherapy/ chemotherapy but also causes a significant economic impact. Therefore, decision-based stratification and triage by telecommunication [11] should be performed for the assessment of severity of the disease, co-existing comorbidities, and logistics. In case of treatment, a special format is needed to take consent for cancer patients specifying the risk involved to self and to the attended and outcome mortality difference. All MDTs for managing cancer patients should be organized on virtual telecommunication [12].

Two studies published in China and Taiwan revealed that treatment delays in category II and category III were independent risk factors for increased cancer-related mortality. Delay

Table 2 SSO guidelines in alliance with BSO and ISO have proposed three categories as follows

\begin{tabular}{lll}
\hline Category I & $\begin{array}{l}\text { Low-risk patients } \\
\text { with non-life } \\
\text { threatening disease }\end{array}$ & $\begin{array}{c}\text { The treatment can be } \\
\text { postponed for } 6 \text { to } \\
8 \text { weeks after } \\
\text { telecommunication }\end{array}$ \\
Category II & $\begin{array}{c}\text { Intermediate-risk patients } \\
\text { presenting with non-life } \\
\text { threatening disease, but } \\
\text { with a potential for fur- } \\
\text { ther increase in morbidity } \\
\text { and mortality } \\
\text { if there is a delay } \\
\text { course radiotherapy can } \\
\text { in treatment }\end{array}$ & \\
& & \\
Category III & High- risk patients, with life \\
threatening disease & Surgery is proposed \\
&
\end{tabular}


of 3 months showed a drop of 1-year survival from 91 to $60 \%$ and decrease in 5-year survival from 71 to $38 \%$.

\section{Consensus Guidelines for Prioritization of Surgeries}

In the face of pressures placed by the COVID-19 pandemic, elective surgeries have been restricted to alleviate the risk of transmission of the virus among patients and OR staff during aerosol-generating procedures and to preserve essential resources [13-15]. Few guidelines have been offered from surgical societies to help address details for different surgical considerations and prioritization $[16$, 17]; however, these guidelines provide only very broad rather than very specific recommendations. Facility's resources, priorities, and patient needs must be taken into account, and prioritization process should be adjustable to meet local, regional, and national circumstances [18]. A surgical review committee, comprising of surgeon, anesthetist, and nursing personnel, is essential to provide defined, transparent, and responsive guidelines for the hospital. The expert panel recommended certain guidelines to support health service leaders by identifying key domains that should be covered in pandemic preparedness plans.

While elective surgical and endoscopic cases remain on hold, emergency procedures cannot be postponed. These surgeries require careful planning and prioritizing to ensure proper treatment and safety measures are taken. Surgery must proceed regardless of knowing whether or not the patient is COVID-19 positive in emergency situations where surgeries that cannot wait for the results of a 12-h test. If a COVID-19 positive case is identified, it is vitally important to isolate them from new patients and other staff members. This may need to be followed up with referral to a COVID-19 hospital. Elective surgeries should be commenced once COVID-19 curve shows a continuous decline for 15 days. However, the expert consensus group recommends that surgeons follow local State \& Ministry of Health \& Family Welfare (MoHFW) guidelines in this regard.

\section{Consensus Guidelines for Precautions to Be Taken During OPD Procedures and Visiting ER Rooms}

- Routine OPD work should be kept to a minimum. This will ensure less crowding and reduce transmission outside clinics. If avoidable, no relatives should be allowed and social distancing must be practiced within clinics and hospitals, with waiting-room chairs placed six feet apart, and all patients/attendants must wear a mask in the waiting area and should be instructed on cough and sneeze hygiene.

- Doctor's clinics should be well ventilated and patients should maintain minimum six feet social distance except during physical examination.

- The doctor should wear a surgical mask, a face shield, and scrub hands with soap and water and use an alcohol-based disinfectant after interaction with each patient.

- In case of minor surgeries in the OPD, patients must be explained about individual risks of coming to the hospital, office, or surgery center for surgery during the pandemic.

- Essential minor surgeries must only be performed after screening and wearing adequate PPE preferably under local or regional anesthesia.

- There are many surgical procedures that are not considered emergency; hence, it is recommended to look for non-surgical options if available.

- While visiting patients in ER, initial consultation should be performed via phone with the casualty staff.

- History taking and asking for necessary investigations must be done on phone, and the patient is to be examined only after ensuring that he/she does need an emergency surgery.

- All precautions must be taken in order to minimize contact with the patient and relatives.

- Only one attendant is to be allowed with the patient. Social distancing norms are to be maintained as far as possible.

\section{Consensus Guidelines for Personal Protective Equipment}

PPE are designed to protect the health care workers by minimizing the exposure to biological agents [19]. Standard components of PPE kit include a face shield, goggles, mask, gloves, cover all/gowns, head cover, and shoe cover. However, all PPE are not similar. The Association of Spanish Surgeons [20], as well as the Centers for Disease Control in both the USA [21] and in China [22], specifically recommend use of $\mathrm{N} 95$ respirators without valves for surgeries with aerosol-generated procedures on COVID-19 patients. Australia's Department of Health encourages N95 use for "high-level contact" with infected patients [23].

The World Health Organization (WHO) recently published PPE guidance and preventive measures such as hand rub with $70 \%$ alcohol before wearing and after removal of gloves, but did not specify that surgical procedures required N95 respirators [24, 25]. On contrary, MOHFW recommended two types of masks, triple-layer medical mask and $\mathrm{N}-95$ respirator mask, depending upon the personnel and work environment [19]. However, it is encouraged that the healthcare workers must take preventive measures in strict accordance with the 
epidemic assessment level [26]. In addition, Table 3 summarizes recommendations from expert panel on the optimal use of PPE and its disposal for protecting surgeons while performing their duties.

\section{Consensus Guidelines on Classifying Urgent Category Surgeries and Adapting Surgical Techniques to Reduce Exposure Risks}

During the beginning of the COVID-19 pandemic, surgeries were classified into various tiers depending on the urgency of surgery. Most elective surgeries like hernia (up to tier 2b) were advised to be postponed. For most cancer surgeries (tier $3 \mathrm{a}$ and $3 \mathrm{~b}$ ), postponement is not advised by ACS at the moment though it may subject to change [27].

On contrary, aerosol-generating procedures (AGPs) are procedures performed on patients that are more likely to generate higher concentrations of infectious respiratory aerosols than coughing, sneezing, talking, or breathing. The evidence on the possibility of patient to surgeon transmission of SARS-
$\mathrm{CoV}-2$ during droplet- and aerosol-generating procedures is still sparse [28]. However, it is important to recognize that open surgical procedures can generate plume with similar devices. Previous evidence identified the viral and bacterial aerosols in surgical plumes in both laparoscopic and open procedures [29-32]. Smoke evacuation device usage in line with pre-existing OR guidelines may reduce aerosol exposure in both open and laparoscopic procedures [33]. Although laparoscopy is found to result in decreased length of stay and faster recovery as compared with open surgery, it is unclear about the extent of surgeon risk of exposure to aerosolized viral particles during laparoscopy as discussed earlier. Recommendations from CDC suggest the use of enhanced respiratory PPE greater than N95 level for certain aerosolgenerating procedures [34].

The American College of Surgeons stated an insufficient evidence to recommend for/against an open versus laparoscopy approach. SAGES guidelines recommend the use of filters for the released $\mathrm{CO}_{2}$ during laparoscopy and robotic surgery. In Table 4, expert panel provided reasonable recommendations for the list of AGPs, current surgical practices, and

Table 3 Recommendations for use of PPE for surgeons [19]

\begin{tabular}{|c|c|c|c|c|c|}
\hline Sr. No. & Setting & Activity & Risk & Recommended PPE & Remark \\
\hline \multicolumn{6}{|c|}{ A. Outpatient } \\
\hline 1 & Doctor chamber & Provide information to patient & Mild risk & $\begin{array}{l}\text { - Triple-layer mask } \\
\text { - Latex examination gloves }\end{array}$ & $\begin{array}{l}\text { No aerosol-generating procedure } \\
\text { should be allowed }\end{array}$ \\
\hline 2 & $\begin{array}{l}\text { Pre-anesthetic } \\
\text { check-up clinic }\end{array}$ & Pre-anesthetic check-up clinic & Moderate risk & $\begin{array}{l}\text { - N-95 mask } \\
\text { - Goggles } \\
\text { - Latex examination gloves }\end{array}$ & $\begin{array}{l}\text { * Only recommended when close } \\
\text { examination of oral } \\
\text { cavity/dentures is to be done }\end{array}$ \\
\hline \multicolumn{6}{|c|}{ B. In-patient department (non-COVID hospital and non-COVID treatment areas of a hospital which have a COVID block) } \\
\hline 1 & $\begin{array}{l}\text { Ward/individual } \\
\text { rooms }\end{array}$ & Clinical management & Mild risk & $\begin{array}{l}\text { - Triple-layer medical mask } \\
\text { - Latex examination gloves }\end{array}$ & No aerosol-generating activity \\
\hline 2 & ICU/critical care & Critical care management & Moderate risk & $\begin{array}{l}\text { - N-95 mask } \\
\text { - Goggles } \\
\text { - Nitrile examination gloves } \\
\text { +Face shield }\end{array}$ & $\begin{array}{l}\text { Aerosol-generating } \\
\text { activities performed. } \\
\text { Face shield, when a splash of body } \\
\text { fluid is expected }\end{array}$ \\
\hline 3 & Operation theater & $\begin{array}{l}\text { Performing surgery, } \\
\text { administering general } \\
\text { anesthesia }\end{array}$ & Moderate risk & $\begin{array}{l}\text { - Triple-layer medical mask } \\
\text { - Face shield (wherever } \\
\text { feasible) } \\
\text { - Sterile latex gloves } \\
\text { + Goggles }\end{array}$ & $\begin{array}{l}\text { Goggles for personnel } \\
\text { involved in aerosol-generating } \\
\text { procedures }\end{array}$ \\
\hline \multicolumn{6}{|c|}{ C. Emergency department (non-COVID) } \\
\hline 1 & Emergency & Attending emergency cases & Mild risk & $\begin{array}{l}\text { - Triple-layer medical mask } \\
\text { - Latex examination gloves }\end{array}$ & $\begin{array}{l}\text { No aerosol-generating } \\
\text { procedures are allowed }\end{array}$ \\
\hline 2 & $\begin{array}{l}\text { Emergency } \\
\text { procedure room }\end{array}$ & $\begin{array}{l}\text { Attending to severely ill } \\
\text { patients while performing } \\
\text { aerosol-generating proce- } \\
\text { dure }\end{array}$ & High risk & $\begin{array}{l}\text { - Full complement of PPE } \\
\text { (N-95 mask, coverall, } \\
\text { goggle, Nitrile } \\
\text { examination gloves, } \\
\text { shoe cover) }\end{array}$ & \\
\hline
\end{tabular}

Single-use PPE should be disposed of in a red plastic bag, which is sealed and then sprayed with $1 \%$ hypochlorite solution. It should be labeled as HAZMAT and then disposed of as per biomedical waste disposal protocol 
Table 4 Recommendations on surgical practices and postponement of surgeries

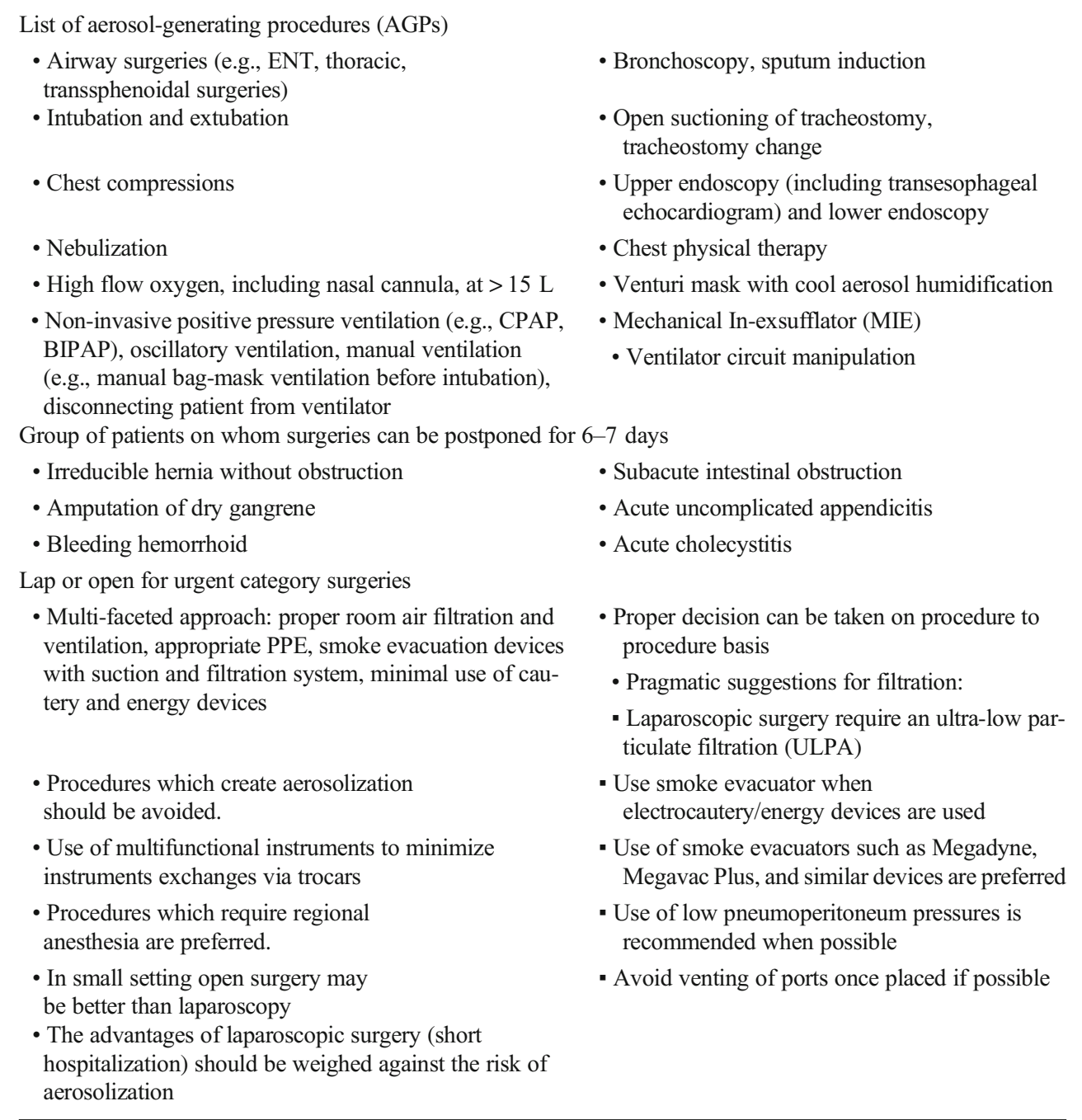

postponement of surgeries in group of patients. Table 5 shows comparison of different risk factors across open, laparoscopic, and robotic-assisted surgery under COVID-19 circumstances.

\section{Consensus Guidelines on Organizing Emergency Surgery, COVID Testing, and Post-operative Care}

Healthcare centers must organize dedicated protocols and workforce training. Usage of surgical appliances and staff must be well contemplated and balanced [37]. Surgical procedures on all suspected COVID-19 patient should be postponed wherever possible until infection clearance is confirmed. However, a fundamental issue in emergency surgery is to consider every patient as COVID positive in order to minimize infection spread and usual precautions must be taken. Before discharge, COVID-19 test is not recommended for patients, as per current Govt. guidelines. In Table 6, the expert panel outlines recommended clinical pathways during lifethreatening emergencies, consensus on testing patients before discharge, and minimizing the contamination risk to the patients postoperatively.

\section{Consensus Guidelines on Diagnosis/Treatment of Post-op COVID Complications, and Surgical Recommendations on COVID-Recovered Patients}

Latest evidence suggests that surgery may accelerate and aggravate disease progression of COVID-19 [14]. All patients developed COVID-19 pneumonia shortly after surgery with abnormal findings on chest computed tomographic scans. Considering the evidence available, expert panel looked into these concerns and following recommendations were outlined to address these challenges as depicted in Table 7. 
Table 5 Risk comparison of open, laparoscopic, and robotic-assisted surgery under COVID-19 circumstances [35, 36]

\begin{tabular}{|c|c|c|c|}
\hline Particulars & Open surgery & Laparoscopy surgery & Robot-assisted surgery \\
\hline Health personnel & Usually 3 bedside staff & Usually 3 bedside staff & $\begin{array}{l}\text { Usually } 1 \text { bedside staff, } \\
1 \text { console staff (remote) }\end{array}$ \\
\hline Length of stay (LOS) & Longer & Short & Short \\
\hline Aerosol generation & $\begin{array}{l}\text { Less aerosol formation, unconfined } \\
\text { dispersion, unfiltered (no data on } \\
\text { COVID-19 in aerosols and risk) }\end{array}$ & $\begin{array}{l}\text { Intraabdominal dispersion, limited by } \\
\text { filters or locks (no data on } \\
\text { COVID-19 in aerosols and risk) }\end{array}$ & $\begin{array}{l}\text { Intraabdominal dispersion, limited by } \\
\text { filters or locks (no data on } \\
\text { COVID-19 in aerosols and risk) }\end{array}$ \\
\hline Smoke & Maximal exposure & Confined, filtered & Confined, filtered \\
\hline Blood, Bio-fluids & $\begin{array}{l}\text { Additional blood loss, } \\
\text { Continuous exposure }\end{array}$ & $\begin{array}{l}\text { Hardly if any blood loss, exposure at } \\
\text { limited intervals }\end{array}$ & $\begin{array}{l}\text { Hardly if any blood loss, exposure at } \\
\text { limited intervals }\end{array}$ \\
\hline Abdominal pressure $(\mathrm{mmHg})$ & 0 & $10-15$ & $<10$ \\
\hline $\begin{array}{l}\text { Perioperative cleaning } \\
\text { of instruments }\end{array}$ & $\begin{array}{l}\text { Large number of instruments, } \\
\text { heavy blood contamination }\end{array}$ & $\begin{array}{l}\text { Limited number of instruments, less } \\
\text { blood contamination }\end{array}$ & $\begin{array}{l}\text { Large surface of robot, limited } \\
\text { number of instruments, less b } \\
\text { lood contamination }\end{array}$ \\
\hline
\end{tabular}

\section{Consensus Guidelines on Pre-op Screening of COVID-19}

Extending the logic of COVID-19 testing to all admitted patients is reasonable given the cost concerns, and the delay in patient management is taken care of. Currently, there are 3 options available for pre-op screening and the expert panel discussed about availability of each options and the considerations are summarized in Table 8:
Table 6 Recommendations on emergency surgery, COVID testing, and post-operative care
Organizing emergency surgery

- Standard precautions, in a given setting, are far more important than universal testing.

- For instance, a positive report is always positive but a negative report has $30 \%$ chance of being false negative.

- Given the volumes of cases expected and the infrastructure available, precautionary measures may not exist at large number of the lefts in coming months. Hence in an ideal situation, a crucial approach is to keep the services operational while maintaining safety precautions.

- An exposure history and history of respiratory symptoms forms a vital part of initial assessment of the patient to evaluate possibility of COVID.

Post-operative care

- Patients to be kept in separate COVID suspect room/ward and all precautions to be taken

- RT PCR needs to be performed if symptoms develop

Testing patients before discharge

- If possible, get a test done before taking up for surgery and the report may become available before or after surgery. However if not sent before surgery, do it as early as possible after surgery.

- It is important to do the test as patients who are COVID positive and are taken up for elective or emergency surgery are at much higher risk of postoperative mortality of up to $20 \%$. Hence, it is important to document it beforehand.
- Surgeries during pandemic can be divided into 5 categories:

- Emergency surgery $<1 \mathrm{~h}$

- Urgent surgery $<24 \mathrm{~h}$

- Urgent elective surgery $\sim 2$ weeks

- Elective Essential 1-3 months

- Elective(discretionary) $>3$ months

- The first two categories need to be taken up even without COVID report being available.

- The surgery should be performed in separate identified COVID OT with all precautions.

- DO NOT hesitate to transfer patient to COVID-designated facility

- If positive, the patient should be kept in isolation for at least $48 \mathrm{~h}$ if not on ventilator.

- Full protection as per $\mathrm{MOH}$ guidelines

- If patient is known COVID positive, any surgical procedure which can be avoided, must be avoided.

- Refer to COVID-designated hospital if positive 
Table 7 Post-op COVID complications and surgical recommendations
Table 8 Recommendations for Pre-Op screening of COVID-19

Diagnosis/treatment of post-op COVID complications

\begin{tabular}{|c|c|}
\hline Symptoms & $\begin{array}{l}\text { - Fever } \\
\text { - Sore throat } \\
\text { - Respiratory difficulty }\end{array}$ \\
\hline Signs & $\begin{array}{l}\text { - Tachypnea } \\
\text { - Tachycardia } \\
\text { - Hypertension } \\
\text { - Bilateral chest creps/wheeze, air hunger } \\
\text { disproportionate to signs }\end{array}$ \\
\hline Investigations & $\begin{array}{l}\text { - CXR-ground glass-serial worsening. } \\
\text { - HRCT-bilateral ground glass } \\
\text { - ABG-hypoxia }\end{array}$ \\
\hline $\begin{array}{l}\text { Treatment (ICU monitoring and supportive } \\
\text { treatment in consultation with intensivist) }\end{array}$ & $\begin{array}{l}\text { - } \mathrm{O} 2 \\
\text { - Ventilation } \\
\text { - HCQ } \\
\text { - Steroids } \\
\text { - Anti-inflammatory }\end{array}$ \\
\hline \multicolumn{2}{|l|}{ Operating on COVID-recovered patients } \\
\hline $\begin{array}{l}\text { - Two consecutive swabs are negative in a } \\
\text { span of } 7 / 14 \text { days } \\
\text { - Antibody spot test-IgM is negative } \\
\text { - Antibody spot test-IgG is positive }\end{array}$ & $\begin{array}{l}\text { - The grade of severity of COVID- } 19 \text { in these patients have to } \\
\text { be assessed, which depends whether they were managed in } \\
\text { the ward or by quarantine, or in the ICU. } \\
\text { - The lung changes are reported to be reversible }\end{array}$ \\
\hline
\end{tabular}

RT-PCR

Antibody spot rapid test

HRCT
- RT PCR (though with false negativities reported) still remains the only investigation to guide a surgeon.

- RT-PCR is positive within 5 days with a sensitivity of $71 \%$ if done within $72 \mathrm{~h}$

- The test will be negative during incubation period but the patient can still be infective.

- There is reported $10 \%$ negativity due to procedural errors.

- The reported shortage of kits coupled with its consumption for pre-op screening at the expense of diagnosis, will make such practice an unethical one.

- Imbalance between availability of these kits between government and private hospitals can raise an alarm.

- Value of resorting to RT PCR after 1 week of infection is minimal.

- A negative RT-PCR hence gives ONLY a false sense of security.

- Antibody spot rapid test can be done only in the 2nd week and has a sensitivity of $81 \%$.

- A HRCT chest may be option to suspect impending COVID status and take post-operative measures to decrease morbidity and mortality. A study on 1100 patients was done in Tongji Hospital, Wuhan, China, and the paper was published in the journal of Radiological society of North America, on Feb 26, 2020.

- HRCT lung-is more sensitive and outperformed lab tests in the diagnosis of Novel COVID-19. It is a more reliable, practical, and rapid method of diagnosis.

- In patients with negative RT-PCR, 75\% were found to have positive HRCT chest finding, and among the $75 \%$ of HRCT positive patients, it was further found that $48 \%$ were high risk, and $33 \%$ belonged to low risk.

- The advantages of HRCT include:

It is a plain CT

NPO not required

Contrast not required

Results available immediately 


\section{Consensus Guidelines on Ideal OT Specifications and Practicalities}

Ideal operation theater specifications are still under consideration. One important recommendation is negativepressure operation room. The use of stapler is preferred as it reduces operation time coupled with other better clinical outcomes [38].

In Indian set-ups, there are three types of hospitals:

a. Small-size nursing home set-up with single operation room

b. Mid/large-size private institutes with multiple operating rooms (in one place or at different places)

c. Mid/large-size public-funded institutes with multiple operating rooms (in one place or at different places)

Sudden changes incorporated to ideal operation rooms will not be possible in all the above set-ups. In cases of multioperation room set-up, a dedicated operating room may be ear-marked. In the post lock-down period, it is advisable to have dedicated COVID theaters. Have separate donning and doffing area. However, the suggestion at present would be:

\begin{tabular}{|c|c|}
\hline$\triangleright$ Stagger the operations & $\triangleright$ No visitors or observers in $\mathrm{OT}$ \\
\hline $\begin{array}{l}>\text { Minimum } \mathrm{HCWs} \text { in operating } \\
\text { room during anesthesia }\end{array}$ & $\begin{array}{l}>\text { Controlled smoke (aerosol) } \\
\text { evacuations - suggestions are } \\
\text { still dynamic }\end{array}$ \\
\hline $\begin{array}{l}>\text { Complete PPE protection } \\
\text { during surgery }\end{array}$ & $\begin{array}{l}>\text { Minimum } \mathrm{HCWs} \text { during } \\
\text { reversal from anesthesia }\end{array}$ \\
\hline$\triangleright$ Use of minimal energy source & $\begin{array}{l}>\text { Sanitize the room with } 1 \% \\
\text { hypochlorite solution (every } \\
\text { equipment used) }\end{array}$ \\
\hline $\begin{array}{l}\triangleright \text { Surgeons and personnel not } \\
\text { needed for intubation should } \\
\text { remain outside the operating } \\
\text { room until anesthesia induction } \\
\text { and intubation are completed for } \\
\text { patients with or suspected of } \\
\text { having COVID-19 infection }\end{array}$ & $\begin{array}{l}>\text { Keep the doors of OT open for } \\
\text { sufficient time between cases } \\
(1 \mathrm{~h} \text { between cases })\end{array}$ \\
\hline
\end{tabular}

\section{Key Recommendations on Additional Measures}

- The risk of transmission of COVID-19 through transfusion of blood and components is now only theoretical and likely minimal [39]. There is no restriction on blood transfusion. Any actions taken to mitigate risk are therefore precautionary. Guidelines issued by National Blood Transfusion Council, MoHFW, and standard laboratory biosafety practices, based on national or international guidelines, should be followed in all circumstances.
- With regard to medico-legal aspects, there is no law on COVID morbidity and mortality. Hence, one has to be guided by the notification issued by the MoHFW. A separate consent explaining morbidity and mortality of surgery is advisable.

- Costs get escalated with use of PPE for all involved in surgery and postoperative care. It is estimated to be over Rs. 15,000 per case. Agencies like ESI/CGHS/ECHS and even insurance need to be informed and directed through the MoHFW to exclude the cost from the package for operations agreed upon.

- Surgeons above 65 years are advised to avoid getting into health care activities during the COVID era. The proposed blanket insurance for healthcare workers by central government will not become applicable to such people in case the infection is proved to be from clinical practice.

- COVID-19 will not disappear anytime soon and will be part and parcel of our lives in the foreseeable future. And therefore, any travel or on-site meetings will pose a definite risk to the healthcare personnel. The governmental policy (updated from time to time) would guide the future with specific regard to conducting/attending such meetings. ASI's flagship annual Regional Refresher Courses and the newly introduced National Skills Enhancement Programme for postgraduates (NSEP PGs) starting in June 2020 ushers in a new era in the Association's elearning teaching schedule.

- Revised ICMR guidelines recommend hydroxychloroquine as chemoprophylaxis for all asymptomatic healthcare workers involved in containment and treatment of COVID-19 with dosage of $400 \mathrm{mg}$ twice a day on day 1 , followed by $400 \mathrm{mg}$ once weekly for next 7 weeks, to be taken with meals. It further recommends use beyond 8 weeks on weekly dosage with strict monitoring of clinical and ECG parameters, and one ECG should be done anytime during the course of prophylaxis [40].

\section{Conclusion}

In a very short period, health care systems and society have been tremendously impacted by COVID-19. It appears that the fight against this pandemic disease will be long-lasting. The proposed mitigation strategies highlighted by this expert panel underscore the urgent need for revised decision-making and appropriate resource allocation, which would enable the broader healthcare community to prevail during these difficult times. It is important to have robust mechanisms, strategies, and protocols in place for infection prevention, screening/triage, use of PPE, modification of infrastructure, and processes, while taking utmost care to protect the healthcare professionals, all along. These consensus guidelines would hopefully enable ASI members in performing 
their professional responsibilities without being the pivot of disease transmission. Most importantly, it is also crucial to evaluate the effectiveness of adapted strategies more often for longer-term health system capacity building.

This advisory was prepared based upon information available up to 26 May 2020. COVID-19 is a fast-changing scenario and practice guidelines may change accordingly. Looking up the Indian Council of Medical Research (ICMR) and MOHFW websites from time to time is essential to get the latest and up to date information.

\section{Compliance with Ethical Standards}

Conflict of Interest The authors declare that they have no conflict of interest.

Ethical Issues NIL

Consent to Participate NA

\section{References}

1. Our World in Data (2020). Total and daily confirmed COVID-19 cases, India. https://ourworldindata.org/grapher/covid-tests-casesdeaths?country= IND Accessed 26 May 2020

2. All COVID-19 technical guidance by topic: https://www.who.int/ emergencies/diseases/novel-coronavirus2019/technical-guidance. Accessed 25 May 2020

3. Indian council of medical research department of health research. https://www.icmr.gov.in/pdf/covid/strategy/Strategey_for COVID19_Test_v4_09042020.pdf. Accessed 25 May 2020

4. SAGES and EAES recommendations regarding surgical response to COVID-19 crisis. https://www.sages.org/recommendationssurgical-response-covid-19/.

5. Del Rio C, Malani PN (2020) COVID-19 - new insights on a rapidly changing epidemic. Jama 323(14):1339-1340

6. Ministry of Health and Family Welfare, Government of India. Guidelines for notifying COVID-19 affected persons by private Institutions. Available from: https://www.mohfw.gov.in/pdf/ G u i d e 1 i n e s f o r n o t i f y i n g C O V I D 19affectedpersonsbyPrivateInstitutions.pdf. Accessed 23 May 2020

7. American Cancer Society: Infections in people with cancer. Available at https://www.cancer.org/treatment/treatments-andside-effects/physical-side-effects/low-blood-counts/infections. html. Accessed 23 May 2020

8. Liang W, Guan W, Chen R, Wang W, Li J, Xu K et al (2020) Cancer patients in SARS-CoV-2 infection: a nationwide analysis in China. Lancet Oncol 21(3):335-337

9. Novel CPERE (2020) The epidemiological characteristics of an outbreak of 2019 novel coronavirus diseases (COVID-19) in China. Zhonghua liu xing bing xue za zhi= Zhonghua liuxingbingxue zazhi, 41(2), 145

10. Al-Shamsi HO, Alhazzani W, Alhuraiji A, Coomes EA, Chemaly RF, Almuhanna M et al (2020) A practical approach to the management of cancer patients during the novel coronavirus disease 2019 (COVID-19) pandemic: an international collaborative group. Oncologist

11. Brunetti O, Derakhshani A, Baradaran B, Galvano A, Russo A, Silvestris N (2020) COVID-19 infection in cancer patients: how can oncologists deal with these patients? Front Oncol 10:734
12. Clinical guide for the management of cancer patients during the coronavirus pandemic, 17 March 2020, version 1, Available at https:// www.england.nhs.uk/coronavirus/wp-content/ uploads/ sites/52/2020/03/specialty-guide_cancer-and-coronavirus_17march.pdf. Accessed 23 May 2020

13. Clinical issues and guidance. https://www.facs.org/covid-19/ clinical-guidance, Accessed 24 May 2020

14. Lei S, Jiang F, Su W, Chen C, Chen J, Mei W et al (2020) Clinical characteristics and outcomes of patients undergoing surgeries during the incubation period of COVID-19 infection. EClinicalMedicine 100331

15. Aminian A, Safari S, Razeghian-Jahromi A, Ghorbani M, Delaney CP (2020) COVID-19 outbreak and surgical practice: unexpected fatality in perioperative period. Ann Surg Publish Ahead of Print

16. SAGES recommendations regarding surgical management of gastric cancer patients during the response to the COVID19 crisis https://www.sages.org/sages-recommendations-surgicalmanagement-gastric-cancer-covid-19-crisis/. Accessed 24 May 2020

17. Recommendations for prioritization, treatment and triage of breast cancer patients during the COVID-19 pandemic: executive summary https:/www.facs.org/quality-programs/cancer/executivesummary. Accessed 24 May 2020

18. Krishnamurthy, A., \& Gopinath, K. S. (2020). The need for prioritizing cancer surgeries amidst the COVID-19 pandemic. Indian Journal of Surgical Oncology, 1

19. Ministry of Health and Family Welfare, Govt of India, Directorate General of Health Services. Novel coronavirus disease 2019 (COVID-19): guidelines on rational use of personal protective equipment. Available from: https://www.mohfw.gov.in/pdf/ GuidelinesonrationaluseofPersonalProtectiveEquipment.pdf. Accessed 24 May 2020

20. De cirujanos AE. Recomendaciones Para Manejo De Pacientes Con Infección Por COVID-19 En El Contexto De Una Intervención Quirúrgica Urgente O Electiva. AEC Available at: https://www. aecirujanos.es/files/noticias/152/documentos/Recomendaciones caso_cirugia.pdf. Accessed 26 May 2020

21. CDC. Coronavirus Disease 2019 (COVID-19). Centers for Disease Control and Prevention. Available at: https://www.cdc.gov/ coronavirus/2019-ncov/hcp/respirator-use-faq.html. 2020. Accessed 26 May 2020

22. For different groups of people: how to choose masks Available at: http://en.nhc.gov.cn/2020-02/07/c_76344_2.htm. Accessed 26 May 2020

23. Australian Health Department. Interim recommendations for the use of PPE during hospital care of people with COVID-19 Version 2 Available at: https://www.health.gov.au/sites/default/ files/documents/2020/03/interim-recommendations-for-the-use-ofpersonal-protective-equipment-ppe-during-hospital-care-ofpeople-with-coronavirus-disease-2019-covid-19.pdf. 2020. Accessed 26 May 2020

24. World Health Organization. Clinical management of severe acute respiratory infection when novel coronavirus $(\mathrm{nCoV})$ infection is suspected. https://www.who.int/zh/emergencies/diseases/novelcoronavirus-2019/technical-guidance 2020 Jan 25. Accessed 23 May 2020

25. World Health Organization. Rational use of personal protective equipment for coronavirus disease 2019 (COVID-19): Interim Guidance. WHO/2019-nCov/IPC PPE_use/2020.1; WHO Available at: https://apps.who.int/iris/bitstream/handle/10665/ 331215/WHO-2019-nCov-IPCPPE_use-2020.1-eng.pdf. Accessed 23 May 2020

26. Rational use of personal protective equipment for coronavirus disease 2019 (COVID-19) https://apps.who.int/iris/bitstream/handle/ 10665/331215/WHO-2019-nCov-IPCPPE_use-2020.1-eng.pdf. Accessed 25 May 2020 
27. American College of Surgeons. COVID-19: guidance for triage of non-emergent surgical procedures. https://www.facs.org/about-acs/ covid-19/information-for-surgeons/triage 24 March 2020. Accessed 25 May 2020

28. Basso T, Dale H, Langvatn H, Lønne G, Skråmm I, Westberg M, Wik TS, Witsø E (2020) Virus transmission during orthopedic surgery on patients with COVID-19-a brief narrative review. Acta Orthop: $1-4$

29. Stephenson DJ, Allcott DA, Koch M. The presence of P22 bacteriophage in electrocautery aerosols. In: Proceedings of the National Occupational Research Agenda Symposium, Salt Lake City, UT Available at: https://www.researchgate.net/profile/Dale_ Stephenson/publication/242419093_THE_PRESENCE_OF_P22_BACTERIOPHAGE_IN_ELECTROCAUTERY_AEROSOLS/ links/00b7d52a09d15f05f3000000.pdf. 2004.

30. Farmer WM, Nataupsky M, Gorochovskaya R, et al. Identification of Aerosol Production during Surgical Procedures. 00229128; NIOSH Available at: https://www.cdc.gov/niosh/nioshtic-2/ 00229128.html. March 28, 1994.

31. Mellor G, Hutchinson M (2013) Is it time for a more systematic approach to the hazards of surgical smoke? Reconsidering the evidence. Workplace health \& safety 61(6):265-270

32. Schultz L (2015) Can efficient smoke evacuation limit aerosolization of bacteria? AORN J 102(1):7-14

33. Ball K (2012) Compliance with surgical smoke evacuation guidelines: implications for practice. ORNAC J 30(1):14-16

34. Centers for Disease Control and Prevention. Interim domestic guidance on the use of 276 respirators to prevent transmission of SARS from severe acute respiratory syndrome 277 (SARS): https://www. cdc.gov/sars/clinical/respirators.html. May 3, 2005. Accessed 24 May 2020

35. Kimmig R, Verheijen RH, Rudnicki M (2020) Robot assisted surgery during the COVID-19 pandemic, especially for gynecological cancer: a statement of the Society of European Robotic Gynaecological Surgery (SERGS). J Gynecol Oncol 31(3)

36. Porter J, Blau E, Gharagozloo F, Martino M, Cerfolio R, Duvvuri U et al (2020) Society of robotic surgery review: recommendations regarding the risk of COVID-19 transmission during minimally invasive surgery. BJU Int

37. Wong J, Goh QY, Tan Z, Lie SA, Tay YC, Ng SY, Soh CR (2020) Preparing for a COVID-19 pandemic: a review of operating room outbreak response measures in a large tertiary hospital in Singapore. Canadian Journal of Anesthesia/Journal canadien d'anesthésie:1-14

38. Subotic D, Hojski A, Wiese M, Lardinois D (2019) Use of staplers and adverse events in thoracic surgery. J Thorac Dis 11(Suppl 9): S1216-S1221

39. World Health Organization. (2019). Protecting the blood supply during infectious disease outbreaks: guidance for national blood services.

40. Indian council of medical research department of health research. https://www.mohfw.gov.in/pdf/Revisedadvisoryontheuseofhydroxy chloroquineasprophylaxisforSARSCOVID19infection.pdf. Accessed 23 May 2020

Publisher's Note Springer Nature remains neutral with regard to jurisdictional claims in published maps and institutional affiliations. 